\title{
OPPIVIA IHMISIÄ VAI OPPIVIA ORGANISAATIOITA?
}

$\mathrm{J}$

os kysytään, mikä on oppiva organisaatio, ilmeisin ja ehkä juuri siksi harvoin huomioitu vastaus kuuluu: se on metafora. Se on rinnasteinen sellaisille ilmaisuille kuin "aika juoksee" tai "valtio valittaa saamatta jääviä verotuloja". Todellisuudessa ajalla ei ole jalkoja, joilla se voisi juosta. Ei myöskään valtio ole olento eikä sillä ole äänielimiä, joilla valittaa. Puhutun kielemme kontekstissa nämä lauseet eivät kuitenkaan ole mielettömiä. Niillä on mieli, jonka kuka tahansa aikuinen, kieltä hallitseva puhuja ymmärtää. Juokseminen merkitsee nopeaa liikettä, joten tunnetta siitä, että aika kuluu nopeasti voidaan aivan luontevasti ilmaista sanomalla, että "aika juoksee". Metaforan käyttö jonkin ilmiön kuvaamiseen on usein kielellisesti ja ajatuksellisesti rikasta kielen käyttöä. Metaforalle on ominaista tietty iskevyys, metaforan merkitys tuntuu heti ensi kuulemalta itsestään selvältä. Selkeyden tunne on pettävä, sillä metaforalle on ominaista, että se sallii erilaisia tulkintoja itsestään. Kun valtio valittaa saamatta jääneitä verotuloja, mistään ei käy ilmi, onko tämä valitus tuskaisaa ääntelyä, menetyksen tunteen ilmaisua vai juridinen toimenpide, jolla pyritään kumoamaan varhemmin annettu päätös. Milloin metaforaa käytetään tieteelliseen käsitteen määrittelyyn, olisi aina hyvä kysyä a) mitä tällä ilmauksella tarkoitetaan ja b) mitä sellaisia ilmaisun ulottuvuuksia metaforan käytöllä saavutetaan, joita ei saada käyttämällä jotakin täsmällisempää kielellistä ilmausta.

Kun Urpo ja Anita Saralan mukaan organisaatio oppii, he näyttävät tarkoittavan, että organisaatioon kuuluvat ihmiset oppivat. "Oppivan organisaation toimintamallissa organisaatiossa tapahtuvan työnjaon ja toiminnan taustalla on aina tietoinen pyrkimys edistää henkilöstön osaamista" (Sarala \& Sarala 2001, 41). "...työtä organisoitaessa pyritään samalla oppimiselle otollisten tilanteiden ja ilmapiirin aikaansaamiseen..." (Sarala \& Sarala 2001, taulukko 5). "Oppivassa organisaatiossa ihmiset luovat itse todellisuutensa, tiedostavat tämän ja pystyvät muuttamaan sitä' (Sarala \& Sarala 2001, 60). Jos kuitenkin oppivalla organisaatiolla tarkoitetaan pelkästään organisaation jäsenten jatkuvaa op- pimista, mihin tarvitaan itse metaforaa? Saralat eivät tunnu tarvitsevan sitä mihinkään muuhun. Nähtävästi useimmat tutkijat käyttävät oppivan organisaation käsitettä Saraloiden tavoin merkitsemään jonkin organisaation ihmisjäsenten oppimista.

Jos organisaatio oppii, siellä silloin tehdään jotakin uutta, mutta onko organisaation oppiminen aina sidoksissa sen jäsenten oppimiseen, kuten

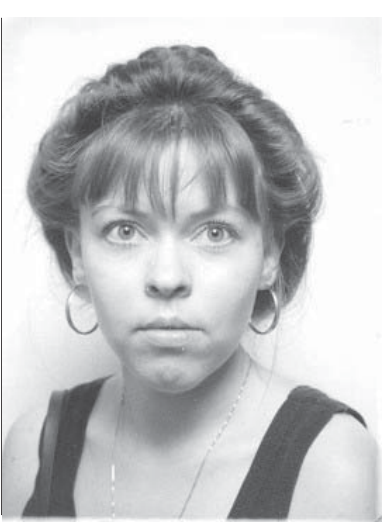

Inka Ukkola Saralat esittävät? Kuvitellaanpa vaikka tehdasta, jonne asennetaan uusi kone, joka valmistaa uudenlaisia tavaroita. Voidaan siis sanoa, että tehdas oppii valmistamaan uudenlaisia tavaroita. Tavaroiden valmistus on tähän saakka vaatinut tehtaan työntekijältä napin painalluksen. Tehtaaseen ostettu uusi kone toimii sekin samanlaisella napin painalluksella, vaikka valmistaakin jotakin uutta tuotetta. Eikö tällaisessa tilanteessa ole mahdollista sanoa, että tehdas on oppinut tuottamaan jotakin uutta, vaikka sen työntekijöiden oppimisessa ei ole tapahtunut sanottavaa muutosta? Jos käytetään metaforaa oppiva organisaatio, eikö sillä pitäisi juuri yrittää nimetä tällaisia kehitysprosesseja, joissa tapahtuu muutos, jota ei voida palauttaa organisaation yksittäisten jäsenten oppimisessa tapahtuneen muutoksen kuvaukseen?

Olen itsekin ollut todistamassa eri työpaikoilla kehitystä ja muutoksia, joita voidaan mielestäni hyvinkin kuvailla sanomalla, että niissä organisaatio oppii. Liikeyrityksessä tällaista oppimista saattaa olla juuri mainittu uusien tuotteiden tai palveluiden valmistaminen. Virastoissa tällaista oppimista voisi olla vaikkapa lainmuutoksen aiheuttama toimintatavan muutos. Molemmissa epäilemättä muutosprosessin ytimessä on organisaation palveluksessa olevien ihmisten - osan tai kaikkien - yksittäisissä oppimisprosessissa aiheutuva muutos. Mutta organisaatioissa tapahtuu aina muutakin: laaditaan uusia lomakkeita, rakennetaan uusia koneita, perustetaan uusia tie- 
tokantoja, kirjoitetaan työnkuvia uusiksi ja niin edelleen.

Toisaalta kaikissa organisaatioissa tapahtuu aika ajoin muutoksia. Voidaan kysyä, ilmaiseeko mikä tahansa muutos organisaatiossa oppimista. Mikä on muuttuvan organisaation ja oppivan organisaation välinen ero? Jos oppiminen on muutosta, voidaanko ero yleensä määritellä? Puhekielessä käsitteet muuttuva ja oppiva eroavat siten, että oppiva kuvaa myönteistä tahdonvaraista prosessia. Myös lahoavat, rapautuvat tai dementoituvat organisaatiot ovat muuttuvia organisaatioita, mutta eivät oppivia. Oppiminen on erityinen muuttumisen muoto, se edellyttää käsitystä siitä, minkälainen muutos on myönteistä, minkälainen ei. Koululaisen edistymistä jonossa etuilun taidossa ei nimitetä oppimiseksi, koska se ei ole opettajien eikä muiden koulutuksesta päättävien henkilöiden tavoitelistalla. Oppimisen rajat määrittelee aina joku, mutta tätä puolta asiasta esim. Saralat eivät teoksessaan käsittele.

Metaforien eräs pitkään tunnettu käyttötarkoitus on elottomien kohteiden inhimillistäminen. Kulttuurin aikakausilla voidaan väittää olevan syntyvaihe, nuoruus, täysi-ikäisyyden saavuttamisen vaihe tai vanhuus. Harvinaista ei ole myöskään kuulla kulttuuri-ilmiöillä olevan oman keväänsä, kesänsä, syksynsä tai talvensa. Näiden metaforien käytöllä voidaan saavuttaa ainakin kaksi etua. Toinen on se, että näin voidaan asettaa yli-inhimillisen kokoinen tarkastelukohde inhimillisiin mittasuhteisiin, ja toinen on se, että näin niihin saadaan käsitteellinen ote, jonka avulla niitä voidaan sen jälkeen mielen ja kielen kei- noin prosessoida edelleen. Kun puhutaan keskiajan syksystä, ajatus kulttuurin historiallisista muutoksista, asettuu mittakaavaan, jossa vuodenkierron eri vaiheet seuraavat vääjäämättä toisiaan. Aikakauden muuttuminen voidaan nähdä vääjäämättömänä prosessina, jolla on omat aikansa ja lainalaisuutensa ja siitä päästä ajatukseen, että kulttuurin muutoksia ohjaavia yleisiä mekanismeja - kuten vuodenaikojen vaihtumistakin koskevia luonnonlakeja - on olemassa ja niitä voidaan myös saada selville. Tarkemmassa tutkimustyössä tällaiset suuren mittakaavan luonnonlait osoittautuvat helposti kestämättömiksi ajatuskonstruktioiksi, mutta niiden käyttökelpoisuus piileekin usein juuri uusien ajattelutapojen ja työhypoteesien koekenttänä. Inhimillinen ajattelu pääsee helpommin operoimaan suurten tai vaikeasti hahmotettavien kohteiden parissa, kun ne on metaforan keinoin saatettu johonkin helpommin käsiteltävään mittakaavaan. Luulen, että oppivan organisaation tärkein käyttötarkoitus onkin muodostaa sellainen hedelmällinen käsitekenttä, jossa organisaatiota voidaan ajatella yksilönä tai organismina ja siten päästä käsiksi sen identiteetin koostumukseen tai hermojärjestelmän rakenteeseen.

\section{LÄHDE}

Urpo ja Anita Sarala (2001) Oppiva organisaatio, oppimisen laadun ja tuottavuuden yhdistäminen. Palmenia-kustannus. 7. painos.

\section{Inka Ukkola}

